\title{
Staphylococcal abscess caused by trauma with a rosebush aculeus (Plantae, Rosaceae): apropos of a case*
}

\author{
Abscesso estafilocócico provocado por traumatismo com acúleo de uma rosa \\ (Plantae, Rosaceae): a propósito de um caso
}

Fred Bernardes Filho
Letícia Soares Sasso

\author{
Gustavo Martins ${ }^{3}$ \\ Gardênia Borges Cenci ${ }^{6}$
}

\begin{abstract}
Cutaneous abscess is a localized collection of pus in the dermis and subcutaneous tissue usually caused by trauma. The authors report the case of a 30-year-old male patient, gardener, that presents an ulcerated plaque in the third right finger, caused by an aculeus plant wound. The examination of the lesion's exudate ruled out the existence of fungi and showed the presence of Staphylococcus aureus. The authors emphasize the sporotrichosis as an important differential diagnosis, especially in endemic areas, and the indication of the exudate culture is discussed.
\end{abstract}

Keywords: Abscess; Rosaceae; Sporotrichosis; Staphylococcus aureus

Resumo: Abscesso cutâneo é uma coleção de pus localizada na derme e tecido celular subcutâneo decorrente, em geral, de traumatismos. Os autores relatam o caso de um paciente de 30 anos, jardineiro, apresentando uma placa ulcerada, no terceiro quirodáctilo direito, provocada por ferimento com acúleo de planta. O exame do exsudato da lesão descartou a presença de fungos e revelou a presença de Staphylococcus aureus. Os autores enfatizam a importância de se lembrar da esporotricose no diagnóstico diferencial, principalmente em regiões endêmicas e discutem a indicação da cultura do exsudato no caso apresentado.

Palavras-chave: Abscesso; Esporotricose; Rosaceae; Staphylococcus aureus

A thirty-year-old male patient, gardener, sought treatment in the emergency department ten days after suffering a puncture wound with a rosewood aculeus. He reported pain and motion limitation of the right hand's third finger. Dermatological examination of the finger showed a plaque with signs of inflammation, tight and very painful. The center was ulcerated and there was drainage of purulent exudate (Figure 1). The proposed hypotheses were: bacterial abscess and sporotrichosis.

Incision and drainage of the exudate were performed and the material was sent for mycological examination, Gram staining and culture for fungi and bacteria. The result was negative for fungi, with growth only of Staphylococcus aureus, which antibiogram showed sensitivity to nearly all tested antibiotics (Chart 1).

Some plants have their own defense mechanisms represented by real thorns, spines, serrated teeth, acutely shaped leaf terminations and barbs that can injure the skin on contact with them, as occurs during handling or in case of an accidental contact without skin protection. ${ }^{1}$

A cutaneous abscess is a localized collection of pus present in the dermis and subcutaneous tissue, usually from streptococcal or staphylococcal etiolo-

Received on 11.06.2013.

Approved by the Advisory Board and accepted for publication on 01.08.2013.

* Work performed at a private practice - Ituiutaba (MG), Brazil.

Conflict of interest: None

Financial Support: None

Post graduation in Dermatology (in course) at Professor Rubem David Azulay Dermatology Institute, Santa Casa da Misericórdia do Rio de Janeiro Hospital (IDPRDA-SCMRJ) - Rio de Janeiro (RJ), Brazil.

Medical Student at Santos Metropolitan University (UNIMES) - Santos (SP) - Brazil.

MD, Dermatologist - Private Practice -- Ituiutaba (MG), Brazil.

MD, Ophthalmologist - Private practice- Ituiutaba (MG), Brazil.

MD, graduated at Serra dos Órgãos Educational Foundation - Teresópolis (RJ) - Brazil.

MD, Specialist in Internal Medicine at Caxias do Sul General Hospital (HGCS) - Caxias do Sul (RS) - Brazil.

(C)2013 by Anais Brasileiros de Dermatologia 


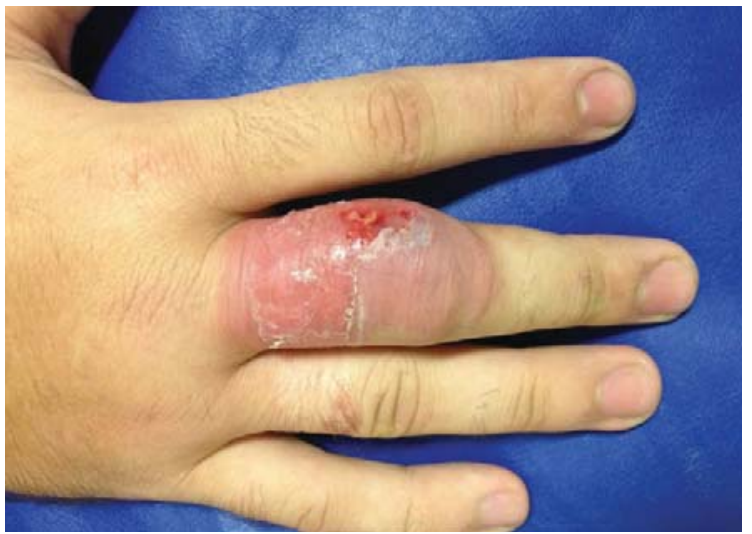

FIGURE 1: Erythematous and edematous plaque with ulceration on the lateral edge of the metacarpophalangeal region and proximal phalanx of the 3rd right finger. Note the presence of a whitish-yellow exudate in the central ulceration

Chart 1: Antibiogram tested with the lesion's exudate

SENSITIVE: Benzylpenicillin, amoxicillin clavulanate, ampicillin, ceftriaxone, cephalothin, erythromycin, cephalexin, ciprofloxacin

INTERMEDIARY: Sulfamethoxazole / trimethoprim

gy, resulting from local trauma, burns, foreign bodies, and sites of intravenous catheter insertion or hematogenous spread. ${ }^{2,3}$ It is clinically recognized by a tight and painful nodule with signs of inflammation, prone to fluctuation and subsequent drainage of pus. ${ }^{2}$ There may be local cellulitis, lymphangitis, regional lymphadenopathy, fever and leukocytosis. The diagnosis is clinical, usually without the need for additional tests. However, the investigation and exclusion of other diagnoses are prudent and should be based on the epidemiological history. Treatment consists of an incision over the fluctuating area, complete surgical drainage of the purulent exudate and irrigation with saline solution. Local heat and elevation may accelerate the resolution of this condition. Antibiotic therapy should be individually evaluated for each case. ${ }^{2}$

The city of Rio de Janeiro has experienced a sporotrichosis epidemic in recent years, and the zoonotic transmission by cats was implicated as the major

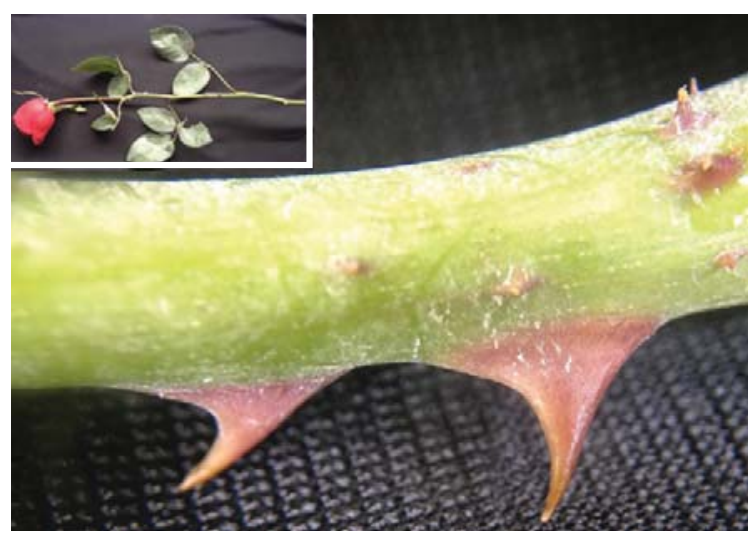

FIGURE 2: Rose aculeus, commonly known as thorn

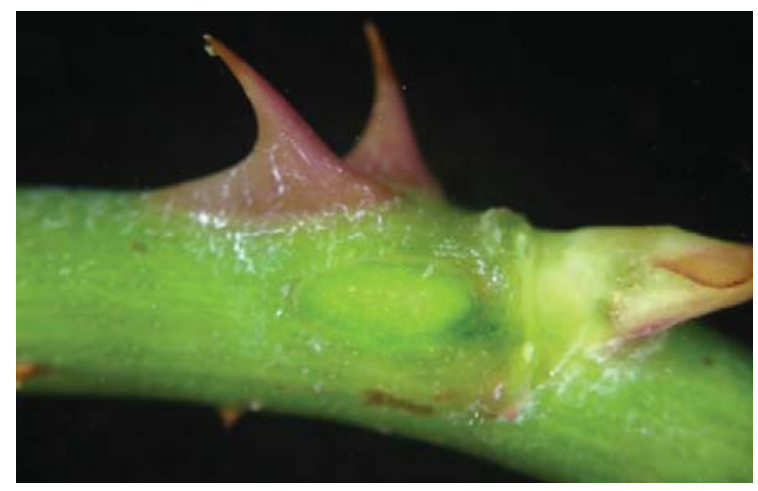

FigurE 3: "Scar" cause by the detachment of an aculeus

villain. ${ }^{4}$ However, this subcutaneous mycosis caused by a fungus of the Sporotrix complex, occurs more frequently among gardeners and straw weavers, and can therefore be seen as an occupational disease. ${ }^{1,4}$ Both clinical forms, cutaneous lymphatic and fixed cutaneous, may present ulcerated, nodular or erythematous infiltrated lesions, similar to our patient's lesion described above.

The injury caused by physical trauma from the contact with plants may be the causative factor responsible for cases of secondary bacterial infections, sporotrichosis or paracoccidioidomycosis. ${ }^{1}$ Culture of the lesion's exudate in this case was indicated because of the possibility of fungal etiology. Although in the present case, the diagnosis is bacterial abscess, the authors emphasize the importance of considering sporotrichosis in the differential diagnosis, especially in endemic regions, since early specific treatment is more effective and reduces the risk of disease complications. 
NOTE: In botany, the spike is an axial organ or appendage resulting from the modification of a branch, usually sprouting from the stem, but that may also be present in the leaves. ${ }^{1,5}$ It is worth mentioning that roses have thorns (aculeus), which are projections on the surface of the stem similar to spines (Figure 2). The aculeus detaches easily, unlike the spikes that originate in the wood's own branch being connected to the vascular system of the plant and therefore more difficult to extract (Figure 3)..$^{5}$

\section{REFERENCES}

1. Reis VMS. Dermatosis due to plants (phytodermatosis). An Bras Dermatol. 2010;85:479-89.

2. Pereira ALC, Leal F, Azulay DR, Azulay RD. Infecções bacterianas da pele (Skin bacterial infections). In: Azulay RD, Azulay DR, Azulay-Abulafia L, editores. Dermatologia. Rio de Janeiro: Guanabara Koogan; 2011. p. 327-47.

3. Haddad V Jr. Cutaneous infections and injuries caused by traumatic and venomous animals which occurred in domestic and commercial aquariums in Brazil: a study of 18 cases and an overview of the theme. An Bras Dermatol. 2004;79:157-67.

4. Ramos-e-Silva M, Vasconcelos C, Carneiro S, Cestari T. Sporotrichosis. Clin Dermatol. 2007;25:181-7.

5. Zeiger E, Taiz L. Fisiologia vegetal (Vegetal Physiology). 5 ed. Porto Alegre: Artmed; 2013.

\author{
MAILING ADDRESS: \\ Fred Bernardes Filho \\ Rua Marquês de Caxias, $n^{\circ} 9$ / Sobrado \\ Centro \\ 24030-050 - Niterói -RJ \\ Brazil \\ E-mail:f9filho@gmail.com
}

How to cite this article: Bernardes Filho F, Alves AO, Martins G, Sasso LS, Gama CM, Cenci GB. Staphylococcal abscess caused by trauma with a rosebush aculeus (Plantae, Rosaceae): apropos of a case. An Bras Dermatol. 2013;88(6):1036-8. 